\title{
Editorial
}

\section{People before processes}

Many years ago I worked with a large and well-respected direct marketing agency which, in turn, worked for a major company in the leisure sector. That partnership achieved many successes, including creative awards and outstanding business performance.

A centrepiece to this creativity was a mail pack that talked not simply to the leisure company's customers, but also to its customers' children. A nice idea especially where it is an appropriate one.

Until there was an accident at one of the leisure company's sites. A child died. His parents sued the company. Unfortunate. Unpredictable. Tragic.

The company and its lawyers dealt with the parents and their lawyers. Otherwise, life — and marketing went on as usual. At least, it went on as usual right up to three days before the next personalised mailing was due out. One individual - not a director, not a senior manager, not even a lowly junior account handler - remembered the case. And they wondered, aloud, whether someone had had the foresight to remove the details of that particular family from the mailing list.

All hell broke loose. Sitting, waiting to go into the mail, were sacks containing nearly three-quarters of a million items. Enclosed. Sorted.

Luckily, the reminder came in time. There were some anxious hours during which enclosing staff sorted through several thousand mail items by hand (it had been one of their number who raised the alarm in the first place). The item was found, removed and destroyed.

Lucky - whether viewed from the perspective of lawyers embroiled in an already potentially expensive law suit; from the perspective of customer relationship management (CRM) experts, anticipating a public relations (PR) disaster; or from a purely human perspective, not wishing to pile further grief on to a family already fully burdened.

This story touches upon many bases. It is not wholly about CRM, but it has a lesson for CRM managers nonetheless. Which is: it's not the process and the systems that count. It's the people.

At around the same time - and apologies if I have relayed this particular history before - the same agency dealt with two household names in financial services. Both of these companies put out regular mailings to their customers and each was often constrained to provide data some weeks before the mailing was due to go out. Which meant, of course, that a number of individuals selected for mailing would have died before the mailing went into the post.

The reaction of these two organisations was instructive. One took the view that nothing was too much trouble to spare the feelings of its customers. At quite disproportionate expense, it provided us, on a daily basis, with names and addresses of individuals notified as deceased - and these were removed before the mailing went out. 
The second organisation took a very different view. When told that it might risk upsetting or offending approximately 60 people, they asked how much it would cost to avoid this risk. On learning what it would cost, they decided that the cost was too much ... so let the mailings go.

Once more, it is people - and attitudes - and the decisions that spring from both, that influence the way in which customers are viewed and treated.

And so back to (one of) my favourite subject(s) ... No, not trains! Although that is where the story starts. Shortly after the new year began, I needed to make a short round trip - by train on a Sunday. I turned up at the station to discover that the train was, in fact, a bus, and, that as the fares had just gone up, I would be paying extra for the privilege of this mode of transport.

Conditions were not ideal. They were made worse by the operator (Great North Eastern Railway (GNER)) insisting on a fast turnaround of coaches at each end. If you travel frequently, then this is not an exceptionally surprising experience. But it was bad enough for me to wish to complain. Here, we turn from bad to much worse. GNER's 'service centre' wanted me to follow its process - which seemed to include telling them about my complaint and then putting it in writing. The attitude was defensive. At every turn, the assumption seemed to be that by failing to comply with ITS procedures - by wishing to approach the issues in a way that suited me, rather than GNER - I was the problem.

There is little I can do about it. As research has suggested, a key component of CRM is people, rather than processes. However, this link breaks down where a supplier runs a monopoly service or there exist other reasons why individuals have to use that company.
My experience re-inforces two intuitions that I have about 'service centres'. The first is that, for a variety of reasons, many companies blunt the service aspects of these operations by an over-insistence on process and procedure. Often because they have been seduced by the third element in this unholy trinity: IT/automation.

Customers phone call centres expecting service and sympathy. Instead they are told how they should behave.

Secondly, companies that act in this way are storing up an enormous amount of ill will towards themselves. In the past, many places would offer individual customer service, in the search for efficiency, however, this personal - and thoughtful - interface, has now been replaced with systems that are inflexible and unresponsive. Not simply the automated call, which so many find hateful, but also the operator, who, when contact is finally made, is unable to do anything other than follow a script.

Customers do not come away from dealing with call centres in a happy frame of mind. Automation is clearly one cause. Recent research suggests another: that call centres now tend to pick up a range of issues that they are not empowered to deal with. So operatives must either disappoint the customer immediately or attempt to grapple with the underlying system ineffectually and disappoint the customer later.

Ill-will must eventually impact the bottom line. Unhappiness breeds frustration, distrust and hostility. These, eventually, will be taken out on the front line operatives of the companies in question. It is all very well warning consumers of the dire consequences of abusing staff (it is always wrong to do so) but where the company-consumer interface has become drained of the personal touch, it is an inevitable consequence. This creates its own costs, 
in terms of staff turnover, security requirements and passive aggression towards company procedures.

Yet it does not have to be this way. I began this editorial with a story that remains with me nearly 20 years after the event. It highlights the positive impact that empowered and committed people can have on an organisation. I end with a story of the opposite: disempowered, process-driven people doing further harm to a company's reputation.

Between the two extremes lies a good deal of sentiment. It would, after all, be so much 'nicer' if everyone could act positively. It also highlights the absolute importance of two other components for companies trying to get the CRM equation right: audit and experience.

I apologise for touting my own wares ever so lightly: I would emphasise that others have devised similar products at greater or lesser degrees of complexity. However, after years of being enraged by customer services, I have put that rage to good use and contributed to the first component - by devising a service centre audit. This identifies the processes and procedures that separate the good centre from the bad and enables any organisation to score its own performance on that basis. It is an interesting project and, having worked on it, I now find myself almost unconsciously ticking off boxes every time I have to deal with a new call centre.

The second component is good old 'mystery shopping'. I am always amazed at how far the real customer experience can lie from what it is supposed to be. Companies that encourage its managers to live their brand - buying from them, using their products, complaining to them - are usually far more switched on to their customers' needs. And even where this is not always possible, they can at least recapture that experience through the more formal exercise of mystery shopping.

And so to the papers. Despite the focus of this editorial — on the human and people side of CRM, this month has tended to go back to the technical side. So, we have 'The case for multi-sourcing prospect pool data' from Julian Berry and Paul Rowson; 'The rise of right-time marketing' from Dan Goldstein and Yuchun Lee; 'Developing retention strategies based on customer profitability' from Evangelos Xevelonakis; and a paper on 'Aligning IT and marketing — the impact of database marketing and CRM' by Kai Wehmeyer. Each of these focuses on, and deals with, a specific technical CRM point.

One paper goes beyond this - and to some extent brings us back full circle to the people side of the equation. It comes from Nicky Kouzeleas, who has looked at direct marketing to children. This is a paper founded on legal considerations. Given the sensitivity of the subject, it is also clearly an area where common sense and a degree of customer empathy should play as large a part as any formal reading of the law. 